\title{
The School Culture Heritage of the Reformation
}

\author{
László Trencsényi*
}

\author{
Received: January 26, 2017; received in revised form: March 14, 2017; \\ accepted: March 17, 2017
}

\begin{abstract}
On the occasion of the 500th anniversary of the Reformation, this essay analyses those educational innovations in the history of central European education that were introduced by the Church reform in the 16th century, following these modernizations and their further developments through the spreading of the universal school systems in the late 18th and early 19th centuries. Drawing examples from the innovations in the college culture of the period, the author emphasises that those pedagogical values established in the 16th century are not only valid today, but are exemplary from the point of view of contemporary education. From these the author highlights: pupils' autonomy (in the form of various communities), cooperation with the teachers and school management and the relative pluralism of values.
\end{abstract}

Key words: reformation, history of education, school culture, colleges, pupils' autonomy, contemporary education.

Vocem prego ('My turn please!') - contributors ask the chairing Preses ('President') to allow them to speak at the scholarly debates at the University of Miskolc, where the student traditions of the town Selmec are still alive and well along with the school culture heritage of the Reformation. This very important aspect (ceremonial function) is left out of Mátyás Bajkó's book, entitled College Culture at the Time of the Enlightenment and the Age of Reformation, published in 1976. Nevertheless, the late Bajkó had been the most prominent Hungarian researcher of the Protestant school culture. His book serves as some sort of 'Sola scriptura' for his fellow researchers.

As well as the Preses, the role of the Etalon ('the fellow of the absolute measure') is not mentioned in Bajkó's work either. During the scholarly meetings, from time to time the Preses demands that the Etalon recites a tongue

\footnotetext{
* László Trencsényi, Eötvös Loránd University, Budapest, Hungary; trenyo@index.hu
} 


\section{Acta Technologica Dubnicae \\ volume 7, 2017, issue 1}

twister. If he manages to perform one without mistakes, the Preses allows his fellow colleagues to drink more wine, but if the Etalon fails, the Preses prohibits further drinking (assuming that all members are mildly inebriated).

Bajkó's work is commendable in many respects. It is his recognition that colleges create a distinctive culture system. In his work, Bajkó describes various functions that young men studying at these Protestant colleges (such as Debrecen, Sárospatak, Pápa, or Nagyenyed) fulfil when running the school's government, the so-called coetus. For instance: the senior (a final year student who was the leader of the coetus), together with the contrascriba (the inspector) and the oeconomus (the financial and economic manager of the school). We learn about many other roles the students fulfilled in running the Protestant college: praeses (the person who was responsible for helping with learning), vigil (night watch), apparitor (morning alarm person), calefactor (stoker), etc. All the above roles the students undertook would be considered today as student participation.

Indisputably, Bajkó's oeuvre (centering around the Protestant school culture) represents indispensable material for the Hungarian educational sciences. Bajkó is the spiritual heir of Ernő Fináczy's (Fináczy, 1927) legacy (an outstanding 19th century scholar of the traditional education history research), along with István Mészáros (Mészáros, 1984). In Bajkó's oeuvre the educational history is interwoven with comparative sciences. The same methodology is applied by his eminent follower János Ugrai. The latter combines Viktor Karády's historical sociology with classical educational history discourse to explore the main episodes of the history of college culture (Karády, 1977).

Nevertheless, the topic of my essay is the 'real' Sola scriptura: the practice of these Protestant colleges - a subject that is topical on the eve of the 500th anniversary of the Reformation.

It is notable that the Hungarian terminus technicus, 'Iskolakultúra' (school culture) was coined by Bajkó; and it is widely used today among scholars as part of the academic discourse. As a term triggering complex debates about school, it has also become the title of one of the most prominent Hungarian educational journals.

What is the main pedagogical and scholastic message conveyed by the Reformation? First of all, the fact that the norms and objectives are for our 'worldly existence' here and now, which is a Copernican revolution emphasizing the individual's mission by superseding the 'valley of death' concept. The significance of this shift is that from this moment on, the aim of pedagogy changed, and it was operating within a new paradigm: instead of preparation for 


\section{Acta Technologica Dubnicae \\ volume 7, 2017, issue 1}

the afterlife, pedagogy's role was to help the pupils manage their life here and now, and work and live an honorable and respectful life. In that sense, here we are talking about what later Max Weber describes as the Protestant work ethic (Weber, 1958).

Secondly, for the first time, people could directly address the Creator without their priests' mediation. The possibility of this new, direct dialogue had an important impact on moral education and on how we recognize the relationship between one's own responsibilities and ethics. If freedom from God's punishment for our sins cannot be purchased by money, it means accountability for one's own actions. The relevance of this to pedagogy is that this increases people's responsibility, that they are the agents of their own lives, in charge of their actions, and are responsible for them.

Thirdly, Luther's aim to translate the Bible into the mother language of the people, led to the establishment of schools and the idea of general education (where people can learn how to read and write). This not only had a profound effect on the development of literature that is written in the mother tongue, but also changed the system of education, emphasizing "that schools are rather necessary" (quoting János Apáczai Csere, 17 c. Transylvanian theologian and educational expert).

Fourthly, we must not forget that the concept of necessary and compulsory, universal education originates from the Reformation. This democratic education policy is inherited from the Europe-wide renowned 17th c. educator, Comenius (Vyskočil, 1990). The idea that we are all equal before God and we should all receive education equally bolstered with appropriate didactics is founded in Comenius's principles.

Finally, the implementation of all the principles mentioned above requires a suitable school culture. This school culture was adopted in the Protestant college where the legendary puritanical rigor met serenity, creating a specific "wellthought-out association of students and teachers" (Apáczai, 2003).

As it is known, in those Protestant colleges, there was no sharp distinction between teachers and students. The functions mentioned earlier gave responsibilities to all students. There was also an opportunity to copy and learn important public citizenship models through role-play, by modelling the college after a fictional ancient Roman republic. Through that role-play the pupils not only internalized history but also law and citizenship, via the effective means of learning by doing. In addition, the meaning of the Latin collegium (society), where the word college originates from, denotes the coexistence of people who 


\section{Acta Technologica Dubnicae \\ volume 7, 2017, issue 1}

study together, where everyone is equal, where students and their professors share responsibilities together (see: Jókai, 2005).

The elements of the Selmec-Miskolc school culture are also documented in the 19th century novelist, Jókai's works; its customs (their slang), and the studentedited underground journal that contained banned student songs and texts, the Chronicle of Hush-Castle (Csittvári Krónika), is described in his 1872 novel, 'És mégis mozog a föld' (And Yet It Moves - Eppur si muove) (Jókai, 2010). Through this self-edited journal, the students had an opportunity to develop and practice their own voice and assert their own culture.

All the above examples show that autonomy is a wider concept than selfgovernance, since it is practicing freedom.

We must also mention Mihály Csokonai Vitéz (1773-1805), an outstanding poet of the Hungarian Enlightenment, the forefather of the Hungarian reform pedagogy and drama pedagogy. As a teacher at the Csurgó grammar school in 1799, Csokonai was the first to lead a secular student theatre (he wrote and directed the pieces); and also by holding some of his seminars in a local forest, he could be considered as the forerunner of the practice of forest schools (Szilágyi, 2002).

In addition, we should mention Sándor Kövy (1763-1829), the legendary professor of the Sárospatak College, and his innovation, the so-called 'Pántzélvármegye' (Armour county), whereby in the class he modelled the administration of the era and role-played it with his students in their imaginary county, thus teaching the law, politics and administration to his pupils through enactment. It is recorded that one of the outstanding Hungarian politicians of the 19th century, Lajos Kossuth was one of Kövy's pupils, who played the provost in this role-play. The Sárospatak College was therefore the first school in Hungary that employed the project methodology in teaching. Although Kövy's innovation is considered controversial, I agree with Bajkó, who thinks that it was a place for political socialization, while Ugrai states that it was a successful practice of legal education (Ugrai, 2007).

What followed? What do we think about the 'Nádor-vármegye' (Provost county), a similar endeavor at the same Sárospatak College, that involved the then student Bertalan Szemere, who later became the Hungarian Prime Minister in 1849? Perhaps it can be considered as the forerunner of the democratic school-republic (school-city) system whereby students had autonomous control over their own affairs by practicing responsibilities by acting out historical and contemporary roles (Reilly \& Warneke, 2008; Trencsényi, 1994). 


\section{Acta Technologica Dubnicae \\ volume 7, 2017, issue 1}

All the above examples demonstrate that we are safe to conclude that the innovations of the Reformation had an important influence on contemporary pedagogy and the development of modern school. The 500th anniversary of the Reformation is an anniversary that points beyond its religious significance. Those pedagogical values that were established in the 16th century are not only valid today but are exemplary from the point of view of contemporary education. Namely: pupils' autonomy (in the form of various communities), pupils' cooperation with the teachers and school management, the relative pluralism of values, as well as the opportunity for choice, the possibility for families to select between a variety of educational institutions that offer different pedagogical values and aims.

It is therefore important to pay attention to the college culture of the Reformation, and examine it continuously in order to better understand our cultural heritage and learn from its innovations.

\section{References}

Apáczai Csere, J. (2003). Az iskolák fölöttébb szükséges voltáról (Oratio de summa scholaruum necessitate earumque inter Hungaros barbarici causis). Budapest: Neumann Kht.

Bajkó, M. (1976). Kollégiumi iskolakultúránk a felvilágosodás idején és a reformkorban. Budapest: Akadémiai Kiadó.

Fináczy, E. (1927). Az újkori nevelés története, 1600-1800. Vezérfonal egyetemi előadásokhoz. Budapest: Egyetemi Nyomda.

Heller, Á. (1967). A reneszánsz ember. Budapest: Akadémiai Kiadó.

Jókai, M. (2005). A nagyenyedi két füzfa. Budapest: Nemzeti Tankönyvkiadó.

Jókai, M. (2010). És mégis mozog a föld. Budapest: Fapadoskönyv.hu Kiadó.

Karády, V. (1977). Titres, diplômes et carrières scientifiques universitaires dans la France du 19e siècle. Paris: Centre de sociologie de l'éducation et de la culture.

Mészáros, I. (1984). A humanizmus és a reformáció-ellenreformáció nevelésügye a 15.-16. században. Budapest: Tankönyvkiadó.

Reilly, H., \& Warneke, K. (2008). Father Flanagan of Boys Town. A Man of Vision. Nebraska: Boys Town Press.

Szilágyi, F. (2002). Csokonai a katedrán. In Az ész világa mellett. Budapest: Mundus Kiadó.

Trencsényi, L. (1994). Az iskola-köztársaságok történetéböl. In L. Trencsényi (Ed.), Az alkotmányos pedagógus, Janusz Korczak. Budapest: Állampolgári Tanulmányok Központja - Iskolapolgár Alapítvány.

Ugrai, J. (2007). Önállóság és kiszolgáltatottság. A Sárospataki Református Kollégium müködése 1793-1830. Budapest: L' Harmattan Kiadó. 


\section{Acta Technologica Dubnicae}

volume 7, 2017, issue 1

Vyskočil, F. (1990). Jan Amos Komenský. Kapitoly o jeho predcích, rodičích, pribuzných a mistě narození. Brno: Blok.

Weber, M. (1958). Protestant Ethic and the Spirit of Capitalism. New York: Scribner. 